a

OPEN ACCESS

EDITORES

- Miguel Oliveira Jr. (UFAL)

- René Almeida (UFS)

AVALIADORES

- Pablo Ribeiro (UFRGS)

- Maria José Foltran (UFPR)

- Luísa Godoy (UFVJM)

DATAS

- Recebido: 19/08/2021

- Aceito: 08/09/2021

- Publicado: 08/11/2021

\section{COMO CITAR}

BECHIR, T. (2021). A abordagem da voz passiva em livros didáticos brasileiros. Cadernos de Linguística, v. 2, n. 4, e547.

\title{
A ABORDAGEM DA VOZ PASSIVA EM LIVROS DIDÁTICOS BRASILEIROS
}

\author{
Thaís BECHIR (D) $\bar{x}$ \\ Universidade Federal de Minas Gerais (UFMG)
}

\section{RESUMO}

Neste trabalho, com o objetivo de verificar como se dá a definição e a aplicação da matéria da voz passiva nos livros didáticos brasileiros, analisamos, qualitativamente, 5 livros do Ensino Fundamental II e 5 livros do Ensino Médio, aprovados, respectivamente, pelo PNLD de 2020 e pelo PNLD de 2018. Nesses livros, percebemos uma tendência errônea de limitar a passiva (a) em relação à transitividade verbal, restringindo que ela só ocorre com VTD; (b) em relação a sua semântica, restringindo que ela só ocorre com verbos de ação agentivos. Além disso, notamos que, nesses materiais, a passiva é tratada com ênfase em seus aspectos gramaticais. Mostramos, seguindo a linha de pesquisa da Semântica Lexical, que a passiva não apresenta restrições normativas rigorosas, sejam elas sintáticas ou semânticas. Isso se justifica porque ela se configura como um vasto e poderoso recurso semânticodiscursivo da língua. Assim, propusemos que a passiva seja tratada de maneira mais ampla nos materiais didáticos, com foco, não em regras prontas, mas nas motivações para seu uso e em seus efeitos de sentido.

\section{ABSTRACT}

In this work, in order to verify how the definition and application of the subject of passive voice in Brazilian pedagogical materials is done, we have analyzed, qualitatively, 5 Elementary School books and 5 High School books, approved, respectively, by the 2020 Brazilian Textbook National Programme (PNLD) and by the 2018 PNLD. In these books, we have noticed a wrong tendency to limit the passive (a) in relation to 
verbal transitivity, restricting that it only occurs with direct transitive verbs; (b) in relation to its semantics, restricting that it only occurs with agentive action verbs. Furthermore, we have noted that, in these materials, the passive is treated with emphasis on its grammatical aspects. We have showed, following the line of research of Lexical Semantics, that the passive does not have syntactic or semantic strict normative restrictions This is justified because the passive is a vast and powerful semantic-discursive resource of language. Thus, we have proposed that it has to be treated more broadly, focusing not on readymade rules but on the motivations for its use and its meaning effects.

PALAVRAS-CHAVE

Voz passiva; transitividade; livro didático.

\section{KEYWORDS}

Passive voice; transitivity; pedagogical materials. 


\section{INTRODUÇÃO}

A matéria de vozes verbais tem sido amplamente abordada nos mais diversos livros didáticos brasileiros, sendo apresentada pela Base Nacional Comum Curricular ${ }^{1}$ (BNCC) (BRASIL, 2017, 2018) como uma das habilidades essenciais a serem desenvolvidas em Língua Portuguesa. Sabe-se que o livro didático é um instrumento fundamental para os processos de escolarização do conhecimento, trazendo consigo pressupostos teóricos e métodos específicos. Nesse sentido, ele influencia diretamente o processo de ensinoaprendizagem e a construção dialógica de saberes.

Pode-se dizer que os livros didáticos de Língua Portuguesa são um reflexo dos estudos gramaticais e linguísticos realizados. Por muito tempo, nesses estudos, considerou-se que a voz passiva analítica não poderia ser formada com verbos transitivos indiretos (doravante VTI), sendo admitida apenas por verbos transitivos diretos (doravante VTD) (ROCHA LIMA, 2012, BECHARA, 2009; CEGALLA, 2008; GODOY, 2008; KURY, 2000; CUNHA; CINTRA, 2001). Nesse sentido, tradicionalmente, assume-se que se pode prever a formação de passivas a partir da transitividade, de forma que se o verbo for transitivo direto, ele aceitará essa formação; se o verbo for transitivo indireto, ele restringirá essa formação.

Contudo, essa restrição foi posta em xeque por Bechir (2020). Em uma análise sintático-semântica de VTI e de suas construções em corpora, a autora encontrou vários VTI com a mesma configuração temática que VTD que licenciam a passiva e observou que eles também a licenciam. Vejamos, abaixo, um exemplo com o VTI pisar². Em (1a), temos este verbo sendo utilizado em uma construção ativa. Em (1b), seu uso se dá em uma construção passiva.

(1) a. O público pisou na grama.

b. "Enlameada, a grama foi pisada e arrancada pelo público"3.

Nessa linha, podemos levantar, junto a Bechir (2020), que a passiva não pode ser caracterizada por um viés puramente sintático. Há outros trabalhos que apresentam as propriedades da passiva no PB a partir de abordagens que não são puramente sintáticas. Trabalhos como os de Cançado $(1995,2000)$ e Cançado e Amaral (2016) tratam da passiva sob um ponto de vista semântico-lexical; trabalhos como os Camacho (2000),

1 Disponível em: http://basenacionalcomum.mec.gov.br

2 Fonte: Corpus brasileiro. Disponível em: https://www.linguateca.pt/acesso/corpus.php?corpus=CBRAS. Acesso em: $18 / 06 / 20$

3 Fonte: Web. Disponível em: https://bit.ly/2NAeB4U. Acesso em: 25/11/19. 
Mendonça (2015) e Sallorenzo (2018) tratam da passiva a partir de uma visão funcionalista; trabalhos como os de Ciríaco (2011) e Godoy (2018) tratam da passiva sob um ponto de vista construcional. Esses trabalhos demonstram que a passiva não é um mero mecanismo sintático, mas possui uma motivação semântica, pragmática e discursiva de uso.

Em seu estudo, Bechir (2020) demonstrou que a maioria dos estudos gramaticais e linguísticos consideram que a passivização recebe uma restrição sintática de ocorrência. Contudo, não há estudos que evidenciem, precisamente, como a voz passiva é tratada nos livros didáticos brasileiros em relação a suas restrições. A partir disso, indagamonos: é possível que os livros didáticos apresentem algum insight sobre a possibilidade de passiva com VTI? A passiva é dada como sendo prevista sintaticamente nesses livros? Há definições sobre a formação de passivas elaboradas sob um viés semântico e sob um viés discursivo nesses materiais? Ainda, como esses materiais se relacionam com o que propõe a BNCC (BRASIL, 2017, 2018) sobre o estudo da voz passiva?

Neste trabalho, com o objetivo de responder a essas indagações, verificando como se dá a definição da voz passiva analítica em livros didáticos brasileiros, analisaremos, qualitativamente, 5 livros do Ensino Fundamental II e 5 livros do Ensino Médio das escolas da rede pública de ensino do Brasil. Os livros do Ensino Fundamental analisados foram os do $8^{\circ}$ ano. Quanto aos livros do Ensino Médio analisados, 4 foram do $2^{\circ}$ ano e apenas 1 do $3^{\circ}$ ano. As séries foram selecionadas de acordo com a BNCC (BRASIL, 2017, 2018), que aponta para o estudo da matéria de vozes verbais no $8^{\circ}$ ano do Ensino Fundamental, especificamente, e em qualquer ano do Ensino Médio.

Os livros do Ensino Fundamental selecionados foram aprovados pelo PNLD (Programa Nacional do Livro Didático) de 2020, estando presentes da sala de aula por três anos - 2020, 2021 e 2022. Os livros do Ensino Médio selecionados, por sua vez, foram aprovados pelo PNLD de 2018, estando presentes da sala de aula pelos anos de 2018, 2019 e 2020. Esses livros serão analisados à luz dos estudos em Semântica Lexical (LEVIN, 1993; LEVIN; RAPPAPORT HOVAV, 2005; CANÇADO; AMARAL, 2016). Nessa linha de pesquisa, considera-se que o significado dos verbos está diretamente associado às expressões sintáticas de seus argumentos. Como veremos, a forma sintática do verbo, ou seja, sua transitividade, não parece ser suficiente para explicar a passivização. Por isso, faz-se necessário a adesão de uma abordagem semântico-discursiva para melhor compreender esse mecanismo linguístico.

Tendo em vista que, de forma geral, os livros didáticos elaborados para o ensino de Língua Portuguesa espelham-se em trabalhos gramaticais e linguísticos, e levando em consideração que o trabalho de Bechir (2020) ainda é recente, hipotetizamos que, nesses materiais, a construção na voz passiva é definida sintaticamente, de forma vinculada à transitividade do item verbal. 
Neste trabalho, na seção 1, apresentaremos como a voz passiva tem sido tratada nos estudos gramaticais e linguísticos; na seção 2, apresentaremos a análise da matéria da voz passiva em livros didáticos brasileiros; na seção 3, apresentamos nossas considerações finais.

\section{A VOZ PASSIVA NA LITERATURA GRAMATICAL E LINGUÍSTICA}

As gramáticas tradicionais brasileiras tratam da construção da voz passiva analítica classificando-a a partir de uma visão descontextualizada de sua ocorrência. De maneira geral, consideram que a passiva analítica é formada, sintaticamente, a partir do seguinte esquema: verbo auxiliar ser + particípio passado de VTD + preposição por + agente da passiva, que é opcional. Muitas gramáticas também acrescentam uma abordagem semântica para descrever a passiva, considerando que ela é formada por um verbo de ação com papel semântico de agente. Vejamos um exemplo de sentença na voz passiva: "Nossa casa foi construída pelo engenheiro" (ROCHA LIMA, 2012, p. 313).

A obrigatoriedade de um VTD e de um OD parece fazer parte da "fórmula" para formação de passivas analíticas em gramáticas tradicionais brasileiras (ROCHA LIMA, 2012, BECHARA, 2008; CEGALLA, 2008; KURY, 2000; CUNHA; CINTRA, 2001). Cegalla (2008, p. 355), por exemplo, afirma que, "em geral, só pode ser construído na voz passiva verbo que pede objeto direto, acompanhado ou não de outro complemento". O autor ainda apresenta um esquema de passagem da voz ativa para a voz passiva:

\footnotetext{
Na passagem da ativa para a passiva segue-se o esquema:

$\left.1^{\circ}\right)$ o sujeito da ativa, se houver, passa a agente da passiva;

$\left.2 .^{\circ}\right)$ o objeto direto da ativa, se houver, passa a sujeito da passiva;

$3^{\circ}$ ) o verbo da voz ativa passa para a voz passiva, conservando-se o mesmo tempo e modo. (CEGALLA, 2008, p. 355).
}

Fica claro que, para Cegalla (2008), a passiva é formada a partir de um OD e, consequentemente, a partir de um VTD.

Rocha Lima (2012, p. 307), por sua vez, apresenta que o Ol "desaceita - salvo raríssimas exceções - passagem para a função de sujeito na voz passiva" e usa o critério da passagem para a voz passiva até mesmo para fazer uma distinção entre OD e Ol. Em sua própria definição de Ol, Rocha Lima (2012) afirma que este possui a característica sintática de não aceitar a passiva. Segundo o gramático, o OD pode ser identificado, facilmente, "porque pode ser o sujeito da voz passiva" (ROCHA LIMA, 2012, p. 299). Apesar de o gramático utilizar o termo "salvo raríssimas exceções" quando discute que o Ol não aceita passagem para a posição de sujeito, exemplos não são apresentados e as "exceções" não são discutidas. 
A literatura linguística brasileira, por sua vez, pouco discute sobre a estrutura de formação de passiva, não questionando a "fórmula" dada pela tradição gramatical. Godoy (2008b), por exemplo, afirmou que a passiva é barrada por todo VTI por causa da visibilidade da preposição desses verbos na sintaxe. A autora considera a impossibilidade de formação de passivas com VTI: "selecionamos VTI que tinham a mesma configuração temática de alguns verbos transitivos simples que aceitam a alternância passiva, e percebemos que nenhum dos VTI aceita a alternância” (GODOY, 2008, p. 60). Assim, Godoy (2008) conclui que há uma restrição sintática para a formação de passivas, a saber, que o objeto deve ser direto:

Ou seja, na alternância passiva, antes de se imporem restrições para as configurações temáticas do verbo, impõe-se uma restrição sintática: o argumento complemento que será alçado para a posição de sujeito deve ser um DP. A impossibilidade de formação de passivas com os VTIs acima se deve, portanto, à visibilidade da preposição no componente sintático (GODOY, 2008, p. 60)

Santos (2010), indo em uma direção distinta, se propôs a atestar a passivização de VTI, analisando os seguintes verbos: assistir (no sentido de ver), ajudar, atender, obedecer, pagar e responder. Contudo, como aponta Bechir (2020), o autor trabalha apenas com verbos em que há uma flutuação do uso da preposição; verbos em que as formas direta e indireta coocorrem. Vejamos o comportamento desses verbos (BECHIR, 2020, p. 25):

(1) a. $\mathrm{O}$ menino assistiu ao/o filme.

c. O filme foi assistido pelo menino.

(2) a. A enfermeira ajudou ao/o paciente.

c. O paciente foi ajudado pela enfermeira.

(3) a. A recepcionista atendeu ao/o telefone.

c. O telefone foi atendido pela recepcionista.

(4) a. O filho mais velho obedeceu ao/o pai.

c. O pai foi obedecido pelo filho mais velho.

(5) a. O empresário pagou aos/os empregados.

c. Os empregados foram pagados pelo empresário.

(6) a. O menino respondeu às/as questões da prova.

c. As questões da prova foram respondidas pelo menino.

Todos os verbos apresentados acima, tomados por Santos (2010) como seu objeto de estudo, têm uma ocorrência com preposição e sem preposição de seu objeto (exemplos 
em (a)), possibilitando a passivização (exemplos em (b)). Portanto, o autor refuta, apenas em parte, a postulação de que os VTI não permitem ser construídos na passiva.

Em um trabalho mais recente, Bechir (2020) refuta, de forma mais sólida, a postulação de que a passivização só pode ocorrer com VTD. A autora toma como objeto de estudo os VTI dinâmicos do PB, assumindo-os como verbos biargumentais que exigem um complemento oblíquo preposicionado na posição imediata após o verbo. Inserindo-se na abordagem da linha de pesquisa da Semântica Lexical, a autora realizou uma análise sintática e semântica de $70 \mathrm{VTI}$ do PB, observando seu comportamento. Os dados da autora foram testados em corpora. Bechir (2020) observou, em sua análise, que nem todos os VTI barram a passiva. Na verdade, ela ainda foi além, observando que eles não são simples exceções na língua, mas apresentam-se como a maioria dos VTI. Como ilustra o gráfico abaixo, um total de 37 verbos de sua análise permitem a passiva e apenas 33 a barram.

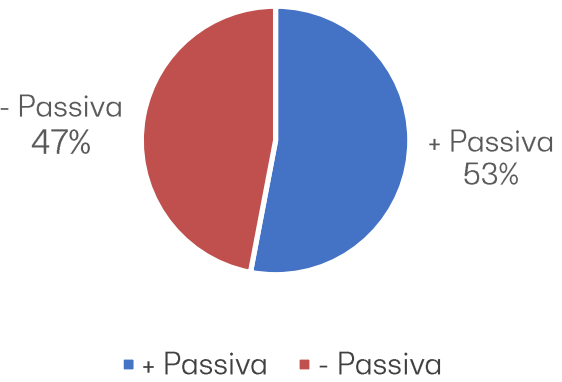

Gráfico 1. Porcentagem dos VTI dinâmicos em relação à passivização. Fonte: BECHIR, 2020, p. 162.

Vejamos alguns exemplos apresentados pela autora (BECHIR, 2020, p. 24). Nos exemplos de (7) a (11), temos VTI que não permitem a passivização. Nos exemplos de (12) a (16), contudo, temos exemplos atestados de passiva com VTI.

(7) a. O cachorro avançou no menino.

b. *O menino foi avançado pelo cachorro.

(8) a. A atriz participou do programa de televisão.

b. *O programa de televisão foi participado pela atriz.

(9) a. O depoente insistiu em sua afirmação prévia.

b. *A afirmação prévia foi insistida pelo depoente.

(10) a. O menino voltou para casa.

b. *A casa foi voltada pelo menino. 
(11) a. O governador desistiu de sua candidatura.

b. *A candidatura foi desistida pelo governador.

(12) a. Alguém judiou de Lula.

b. "Lula reclamou bastante da imprensa, chegando a afirmar que foi judiado"4.

(13) a. O público pisou na grama.

b. "Enlameada, a grama foi pisada e arrancada pelo público"

(14) a. João Pita, Luizão e Marcelo da Santa Casa votaram no presidente.

b. "O presidente foi votado por João Pita, Luizão, Marcelo da Santa Casa [...]”6.

(15) a. Os advogados Daniel Murad Ramos e Jairo Vianna Ramos dissertaram sobre o assunto.

b. "O assunto foi dissertado pelos advogados Daniel Murad Ramos e Jairo Vianna Ramos em evento que reuniu cerca de 40 participantes"?.

(16) a. A equipe do Fantástico debochou de Jair Messias Bolsonaro.

b. "Jair Messias Bolsonaro foi debochado mais uma vez pela equipe do Fantástico, exibido pela TV Globo aos domingos"s.

Vimos que Bechir (2020) atestou a ocorrência de construções passivas com VTI dinâmicos. Oliveira (2020), indo para um caminho similar, observou a possibilidade de construções passivas com VTI estativos. A autora se propôs a analisar, sintática e semanticamente, os verbos de estado do PB, a partir uma proposta inserida na Semântica Lexical assim como a de Bechir (2020). Vejamos algumas sentenças apresentadas por Oliveira (2020, p. 141, 146, 149), em que se demonstra a ocorrência da passiva com VTI estativos:

(17) a. O Romantismo antecede ao Realismo.

b. O Realismo foi antecedido pelo Romantismo.

(18) a. As referências bibliográficas precedem ao apêndice.

b. O apêndice foi precedido pelas referências bibliográficas.

(19) a. O volume da carga excede à quantidade estabelecida.

b. A quantidade estabelecida foi excedida pelo volume da carga.

\footnotetext{
4 Fonte: Web. Disponível em: https://glo.bo/2sEaRls. Acesso em: 25/11/19

5 Fonte: Web. Disponível em: http://bit.ly/2R3QRID. Acesso em: 25/11/19.

6 Fonte: Web. Disponivel em: http://bit.ly/2FZZfCt. Acesso em: 25/11/19.

7 Fonte: Web. Disponível em: http://bit.ly/2NAKMkx. Acesso em: 25/11/19.

8 Fonte: Web. Disponivel em: http://bit.ly/2TAE3eb. Acesso em: 25/11/19.
} 
(20) a. O casal habita em um apartamento novo.

b. Um apartamento novo foi habitado pelo casal.

Observamos, contudo, que os exemplos apresentados por Oliveira (2020), de maneira similar aos apresentados por Santos (2010), apresentam uma flutuação da preposição, visto que todos os verbos podem aparecer sem ela: (17) O Romantismo antecede o Realismo; (18) As referências bibliográficas precedem o apêndice; (19) O volume da carga excede a quantidade estabelecida; (20) O casal habita um apartamento novo. Contudo, realmente há VTI estativos, sem flutuação da preposição, que permitem a passivização. É o caso de alguns verbos de estado psicológico (CANÇADO, 1995, 2002, 2012) alocados no VerboWeb9', um banco de dados lexicais online que estabelece uma classificação sintático-semântica de verbos do PB. Vejamos alguns exemplos que encontramos na Web:

(21) a. "Borges foi antipatizado por muitos intelectuais latino-americanos da época"10.

b. "Entretanto, segundo ele, foi antipatizado por anticomunistas da Suécia"11.

(22)a. "[...] 'porque ela gostava de muita gente e era gostada por muita gente', relembra Bob Wolfenson"12.

b. "Erli era gostado por uns e desgostado por outros"13.

Bechir (2020) mostra que os VTI possuem nuances de sentido muito semelhantes às apresentadas pelos VTD de forma geral, e disso decorrem comportamentos sintáticos também semelhantes. A proposta da autora vai na direção de aproximar esses grupos de verbos, observando que eles não são tão distintos como se pensava.

Bechir (2020) nota que os VTI do PB representam os mais variados componentes de sentido, de forma semelhante ao que ocorre com os VTD. Semanticamente, assim como os VTD, os VTI dividem-se entre todos os quatro aspectos lexicais propostos por Vendler (1967), a saber, estado, atividade, accomplishment e achievement. Semelhanças semânticas mais específicas também foram encontradas entre os VTD e os VTI. Por exemplo, um VTI de atividade como pisar aproxima-se semanticamente de um VTD de atividade como pisotear (BECHIR, 2020), visto que, em ambos, há um tipo de contato

\footnotetext{
9 Disponivel em: http://www.letras.ufmg.br/verboweb/.

10 Fonte: Web. Disponível em: https://bit.ly/3vlYLlq. Acesso em: 18/06/21.

11 Fonte: Web. Disponível em: https://bit.ly/3zRbP1M. Acesso em: 18/06/21.

12 Fonte: Web. Disponível em: https://bit.ly/3qI8PGA. Acesso em: 18/06/21.

13 Fonte: Web. Disponível em: https://bit.ly/2UcsDic. Acesso em: 18/06/21.
} 
mediado pelo corpo do desencadeador (NASCIMENTO, 2015). A estrutura de papéis temáticos proposta para ambos os verbos no VerboWeb é '\{Agente, Objeto Afetado\}'.

Sintaticamente, Bechir (2020) demonstra que os VTI também se aproximam dos VTD. Além da possibilidade de sofrer a passivização, a autora levanta, por exemplo, para o VTD pisotear e o VTI pisar, que ambos: (a) licenciam a inserção de um SP cognato eventivo (AMARAL; CANÇADO, 2015): As crianças pisotearam a boneca com pisões fortes./ As crianças pisaram na boneca com pisadas fortes; (b) formam um SN com o sujeito do verbo na posição de complemento do nome cognato: Os pisões das crianças na boneca a destruíram; As pisadas das crianças na boneca a destruíram; (c) licenciam a fatoração do argumento afetado (MEIRELLES, 2018): As crianças pisotearam as pernas da boneca. - As crianças pisotearam a boneca nas pernas; As crianças pisaram nas pernas da boneca. - As crianças pisaram na boneca/nela nas pernas.

A partir dos verbos de estado psicológico alocados no VerboWeb, também podemos observar que os VTI estativos não apresentam um comportamento tão distinto em relação aos VTD estativos. Semanticamente, o verbo VTD amar e o VTI gostar assemelham-se: de acordo com o VerboWeb, ambos possuem, como conteúdo semântico, o fato de estarem em um estado psicológico em relação a algo. Sendo assim, a estrutura de papéis temáticos de ambos os verbos, como está proposta no VerboWeb, é '\{Experienciador, Objeto Estativo\}'.

Sintaticamente, o VTD amar e o VTI gostar também se aproximam, visto que, além da possibilidade de sofrer passivização, ambos licenciam a fatoração do argumento Objeto Estativo (MEIRELLES, 2018): O rapaz ama o jeito meigo da namorada - O rapaz ama a namorada pelo seu jeito meigo; Os amigos gostavam muito da simpatia da moça - Os amigos gostavam da moça por sua simpatia.

A Semântica Lexical, linha de pesquisa adotada por Bechir (2020) e seguida pelo VerboWeb, postula a existência de uma relação ordenada entre papéis semânticos e papéis sintáticos, de forma que a semântica ordena a sintaxe. Nos estudos nesta linha, assume-se que o comportamento de um item verbal é determinado pelo seu significado (LEVIN, 1993). Segue-se que os VTD e os VTI que possuem as mesmas nuances de sentido possuirão um mesmo comportamento sintático. Assim, a possibilidade de formação de passivas para os VTD e para os VTI, demonstrada pelos dados apresentados por Bechir (2020) e pelo VerboWeb, corrobora a hipótese de ordenação entre a semântica e a sintaxe dada pela Semântica Lexical.

Tendo em vista os dados discutidos nesta seção, questionamo-nos se os livros didáticos possuem algum insight sobre a possibilidade de formação de passivas com VTI. Considerando-se que o trabalho de Bechir (2020) é recente, hipotetizamos que os livros didáticos apresentam como fórmula para a passiva que esta seja formada estritamente com VTD, seguindo trabalhos anteriores, gramaticais e linguísticos, sobre o tema. Nesse 
sentido, nossa hipótese é a de que a passiva seja prevista em termos sintáticos nesses materiais didáticos. Contudo, com relação ao tratamento da passiva sob um ponto de vista funcional e discursivo, já há importantes trabalhos que propõem essa incorporação nos livros didáticos (CAMACHO, 2000; MENDONÇA, 2015; GODOY, 2018). Além disso, há diversos trabalhos que propõem que a gramática deve ser tratada, na escola, não como um conjunto de regras a serem decoradas, mas a partir de seu fundamento social (FRANCHI, 2006; NEVES, 2007; VIEIRA; BRANDÃO, 2009). Sendo assim, é de se esperar que os livros didáticos tratem a passiva levando em conta a motivação para seu uso. Para a análise dos livros didáticos tomados como nosso objeto de estudo, adotaremos a Semântica Lexical, visto que sua metodologia nos possibilitará uma observação de interface entre sintaxe e semântica.

\section{ANÁLISE DOS LIVROS DIDÁTICOS}

Os dados coletados a respeito da formação de passivas originaram-se de um total de 10 livros didáticos das escolas da rede pública de ensino do Brasil. A BNCC, parâmetro curricular que estrutura o ensino brasileiro, definindo "o conjunto orgânico e progressivo de aprendizagens essenciais que todos os alunos devem desenvolver ao longo das etapas e modalidades da Educação Básica" (BRASIL, 2017, 2018, p. 07), conjectura o ensino da passiva no $8^{a}$ ano do Ensino Fundamental II e em qualquer ano do Ensino Médio.

Sendo assim, propusemo-nos a analisar 5 livros do $8^{\text {a }}$ ano do Ensino Fundamental II e 5 livros do Ensino Médio, sendo 4 do $2^{\circ}$ ano e apenas 1 do $3^{\circ}$ ano (o livro "Esferas das Linguagens"). Esses livros foram aprovados, respectivamente, pelo PNLD de 2020 e pelo PNLD de 2018. São eles:
A) Ensino Fundamental II
a) Tecendo Linguagens (OLIVEIRA; ARAÚJO, 2018);
b) Se liga na língua (ORMUNDO; SINISCALCHI, 2018);
c) Português: conexão e uso (DELMANTO; CARVALHO, 2018);
d) Apoema (TEIXEIRA et al., 2018);
e) Geração Alfa (NOGUEIRA et al., 2018).
B) Ensino Médio
a) Novas Palavras (AMARAL et al., 2016);
b) Esferas das Linguagens (CAMPOS; ASSUMPÇÃO, 2016);
c) Viva Português (CAMPOS et al., 2016);
d) Português: contexto, interlocução e sentido (ABAURRE et al., 2016);
e) Ser Protagonista (BARRETO et al, 2016). 


\subsection{A PASSIVA NO ENSINO FUNDAMENTAL II}

De acordo com o BNCC (BRASIL, 2017, p. 191), uma das habilidades a serem trabalhadas no $8^{\circ}$ ano, relacionada a voz passiva, é a habilidade de "identificar, em textos lidos ou de produção própria, verbos na voz ativa e na voz passiva, interpretando os efeitos de sentido de sujeito ativo e passivo (agente da passiva) (EF08LP08)". Essa habilidade é apontada pela BNCC como pertencendo ao objeto de conhecimento da morfossintaxe, apesar do uso do termo "efeito de sentido" nos remeter à semântica. Ademais, a BNCC dita que, no $8^{\circ}$ ano, os alunos devem ser capazes de

\footnotetext{
utilizar, ao produzir texto, recursos de coesão sequencial (articuladores) e referencial (léxica e pronominal), construções passivas e impessoais, discurso direto e indireto e outros recursos expressivos adequados ao gênero textual (EF08LP14) (BRASIL, 2017, p. 191).
}

Nesse caso, a passiva é mencionada juntamente com outras construções e recursos textuais. Para essa habilidade, a BNCC aponta a semântica como objeto de conhecimento. Tanto a habilidade EF08LP08 quanto a habilidade EF08LP14 são dadas dentro do campo de atuação denominado "análise linguística/semiótica".

Nas subseções seguintes apresentaremos como os 5 livros didáticos do $8^{\circ}$ ano do Ensino Fundamental II, os quais tomamos como nosso objeto de estudo, tratam a passiva.

\subsubsection{TECENDO LINGUAGENS}

No livro "Tecendo Linguagens", o assunto de vozes verbais é iniciado a partir de um exercício que requer que os alunos observem os verbos valorizar e trazer a partir de um trecho de um artigo de opinião já tratado no livro. O exercício solicita que os alunos apontem se os sujeitos desses verbos são agentes ou se sofrem a ação dos verbos. A intenção do exercício parece ser a de apontar que esses verbos possuem agentes e não pacientes.

Além disso, em uma próxima questão, é requerido que os alunos respondam qual é a transitividade dos verbos, apontando se eles necessitam ou não de complemento, bem como quais são seus objetos. A intenção desse exercício parece ser a de fazer o aluno reconhecer que tanto o verbo valorizar quanto o verbo trazer são transitivos diretos.

Em seguida, temos, no livro, a definição de voz passiva: "quando o sujeito é o agente da ação expressa pelo verbo, dizemos que o verbo está na voz ativa. Nesse caso, o sujeito recebe a denominação de ativo ou agente" (OLIVEIRA; ARAÚJO, 2018, p. 156). Como podemos notar, definição dada é semântica, nomeando os papéis temáticos dos participantes verbais. Ainda a partir de um critério semântico, é apresentado um quadro explicando como se dá a passagem para a voz passiva: 
Nas orações em que o sujeito não realiza a ação expressa pelo verbo, dizemos que o verbo está na voz passiva, mas recebe a ação. Nesse caso, o sujeito recebe a denominação de passivo ou paciente e o termo que realiza a ação expressa pelo verbo é denominado agente da passiva (OLIVEIRA; ARAÚJO, 2018, p. 157).

O esquema exemplificador da passiva, por sua vez, é dado apresentando também suas propriedades sintáticas. Como podemos notar, nesse esquema, é dado que são os VTD que admitem passivização (OLIVEIRA; ARAÚJO, 2018, p. 157-158):

$\begin{array}{ccc}\text { Nossa sociedade } & \text { exige } & \text { mudanças. } \\ \downarrow & \downarrow & \downarrow \\ \text { sujeito/agente } & \text { verbo transitivo direto } & \text { objeto direto }\end{array}$

$\begin{array}{ccc}\begin{array}{c}\text { Mudanças } \\ \downarrow\end{array} & \text { são exigidas } & \text { pela nossa sociedade. } \\ \text { sujeito/paciente } & \text { verbo na voz passiva } & \text { agente da passiva } \\ & \text { verbo auxiliar (ser ou estar) } \\ & + \text { verbo principal no particípio passado }\end{array}$

Em uma próxima seção do livro, chamada de "aplicando conhecimentos", há exercícios sobre a voz passiva. Nesses exercícios, há verbos como educar, cercar e favorecer, todos VTD. No primeiro exercício, por exemplo, há uma tirinha do Armandinho com o verbo educar e, em uma das perguntas, questiona-se qual é a transitividade do verbo em questão e qual é seu complemento. Podemos inferir que, também em questões como essas, espera-se que o aluno perceba que a passiva é formada a partir de VTD.

Pelos exercícios propostos no livro, a única atribuição semântica que a passiva ganha é o fato de ser dada como ocorrendo sempre com verbos com o papel semântico de agente, sendo esse entendido como aquele que pratica a ação do verbo. Contudo, Bechir (2020) mostrou que há VTI não agentivos que formam passivas, como o verbo culminar. Vejamos o exemplo atestado pela autora (BECHIR, 2020, p. 132):

(23)a. A total de ausência de fé na vida e no Criador culminaram no ato de suicídio.

b. "O ato [de suicídio] foi culminado pela total ausência de fé na vida e no Criador"14.

Ademais, Bechir (2020) aponta para um VTD não agentivo que aceita a passiva, cujo comportamento é similar ao do VTI culminar: o verbo acarretar. Vejamos um exemplo: 
(24) a. Um possível aumento na taxa de respiração das sementes acarretou o decréscimo.

b. "Provavelmente, o decréscimo foi acarretado por possível aumento na taxa de respiração das sementes"15.

Observemos que, mesmo intuitivamente, o sujeito de verbos como culminar e acarretar não podem ser vistos semanticamente como praticantes da ação do verbo. Sendo assim, essa definição semântica parece ser problemática para a caracterização da voz passiva.

Podemos concluir que, no livro "Tecendo Linguagens" como um todo, não há previsão de que pode ser possível a passiva com VTI. Além disso, apesar de a passiva ser definida por um viés semântico, ela é dada como sendo prevista sintaticamente. Os efeitos de sentido da passiva que, como sugere a BNCC (BRASIL, 2017, 2018), deveriam ser tratados, não são trabalhados. O que ganha destaque é a estruturação sintática da passiva e os papéis semânticos de agente e de paciente, adotados sem rigor teórico.

\subsubsection{SE LIGA NA LINGUA}

O livro "Se liga na língua", ao introduzir a matéria de vozes verbais, aponta que os verbos podem apresentar três vozes: voz ativa, em que "o sujeito pratica a ação expressa pelo verbo: O menino vende flores", voz passiva, em que "o sujeito sofre a ação expressa pelo verbo: As flores são vendidas pelo menino" e, ainda, apresenta a voz reflexiva (ORMUNDO; SINISCALCHI, 2018, p. 182). A caracterização inicial da passiva, portanto, é dada a partir de um viés semântico, com uma diferenciação entre os papéis de agente e de paciente.

Contudo, ao iniciar com o título de "voz passiva", a primeira afirmação feita é sintática: "apenas os verbos transitivos diretos podem ser expressos na voz passiva" (ORMUNDO; SINISCALCHI, 2018, p. 183). Um esquema para a formação da voz passiva analítica é dado, apresentando, como podemos notar, um VTD (ORMUNDO; SINISCALCHI, 2018, p. 183):

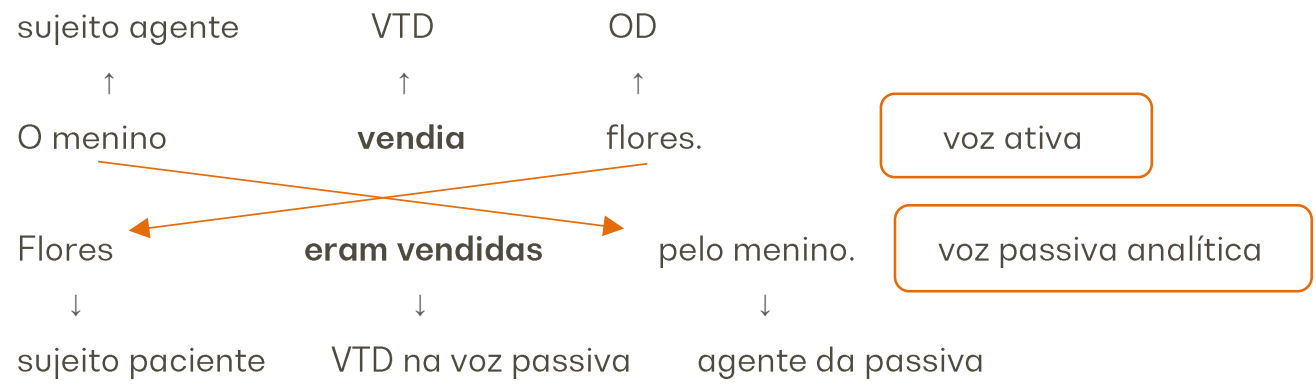

15 Fonte: Scielo Brasil. Disponivel em: https://bit.ly/2TQWXQt. Acesso em: 18/06/21. 
Na seção de exercícios, denominada "vozes verbais na prática", a proposta é mais contextualizada e revela um viés semântico-pragmático além do sintático. A partir de uma notícia, é pedido que se faça uma comparação entre os usos das formas passiva e ativa, mostrando a ênfase dada em cada um deles. Além disso, é pedido que se compare como a informação é transmitida nessas duas formas. Em um outro exercício, é apresentado um poema escrito na voz ativa. A partir disso, é requerido que se explique o porquê de o autor ter escolhido usar essa voz em uma sentença com o VTD ouvir e como a mudança para a voz passiva poderia alterar a informação. Muito interessante também é o quadro que o livro apresenta, denominado "A língua nas ruas" que instiga o aluno a entender o propósito comunicativo das alternâncias de voz:

\footnotetext{
Você acha que, atualmente, a voz passiva sintética é bastante usada nos textos escritos? Anote a sua hipótese e justifique-a. Em seguida, separe uma página de jornal e verifique ocorrências desse uso. Anote os exemplos no caderno. As páginas devem ser de notícias, reportagens ou textos opinativos (ORMUNDO; SINISCALCHI, 2018, p. 86)
}

Concluímos que este livro didático considera, assim como hipotetizamos, que a passiva analítica só pode ser formada por VTD. Além disso, semanticamente, considera que a passiva só é formada por verbos que atribuem o papel temático de agente ao seu sujeito. Isso é problemático tendo em vista que, como vimos, não parece ser verdade que apenas os verbos agentivos podem sofrer passivização (BECHIR, 2020). Contudo, apesar de a passiva ser prevista em termos sintáticos, um viés semântico-discursivo passa a ser - foco nos exercícios, sendo trabalhada a alternância de voz de forma mais contextualizada aos seus efeitos de sentido, seguindo a BNCC (BRASIL, 2017), e ao seu propósito comunicativo.

\subsubsection{APOEMA}

Na seção "Língua e foco" há uma subseção denominada "Vozes verbais e efeitos de sentido". Primeiramente, são apresentados exemplos de sentenças retirados de um texto sobre Fake News. Em seguida, são dadas as seguintes sentenças (TEIXEIRA et al., 2018, p. 163): "A disputa política pode ser influenciada por essas técnicas" - voz passiva; "Essas técnicas podem influenciar a disputa política" - voz ativa. Ressaltemos que influenciar é um VTD.

Há alguns exercícios que objetivam que o aluno reconheça que o sujeito da voz ativa "pratica" a ação de influenciar e o sujeito da voz passiva "recebe" a ação de influenciar. Sendo assim, uma primeira percepção da passiva é semântica. Algumas definições são dadas:

O sujeito que pratica a ação indicada pelo verbo é chamado de sujeito agente. Sujeito é uma função sintática e sujeito agente e sujeito paciente são funções semânticas, que destacam se o sujeito age ou se ele sofre uma ação. As vozes dos verbos indicam o papel semântico dos sujeitos (...) (TEIXEIRA et al., 2018, p. 163). 
A escolha pelo verbo influenciar como um "verbo de ação" para ilustrar um agente é incoerente, visto que os alunos podem levantar, corretamente, que, se uma técnica influencia uma disputa política, ela não pratica essa ação e nenhuma ação, na verdade. O livro usou um exemplo que levanta um problema para sua própria definição semântica da passiva. Fica claro, a partir do exemplo dado pelo próprio livro didático, que uma definição semântica do sujeito como agente não é acertada.

Em seguida, seguindo uma perspectiva mais sintática, é apresentado um esquema para a formação da voz passiva analítica, que ilustramos abaixo (TEIXEIRA et al., 2018, p. 164):

\begin{tabular}{|c|c|c|}
\hline \multicolumn{3}{|c|}{ Voz ativa } \\
\hline $\begin{array}{c}\text { As fake news } \\
\text { sujeito agente }\end{array}$ & $\begin{array}{c}\text { corroem } \\
\text { verbo transitivo direto }\end{array}$ & $\begin{array}{c}\text { a credibilidade da } \\
\text { imprensa. } \\
\text { objeto direto }\end{array}$ \\
\hline & $\begin{array}{c}\text { écorroída } \\
\text { locução verbal } \\
\text { sujeito paciente }\end{array}$ & $\begin{array}{c}\text { pelas fake news. } \\
\text { agente da passiva }\end{array}$ \\
\hline \multicolumn{2}{|c|}{ Voz passiva } \\
\hline
\end{tabular}

Como podemos notar, o esquema acima ilustra que deve haver um VTD na voz ativa para que possa ser feita sua transposição para a passiva. Ademais, nos exemplos dados pelo livro, há apenas VTD: influenciar, atropelar e corroer. Assim, não há previsão da ocorrência da passiva com VTI.

Os "efeitos de sentido da passiva", que dão nome à seção, são trabalhados superficialmente em alguns exercícios. A partir de um título de uma notícia, pede-se que os alunos expliquem qual seria o efeito de sentido trazido pelo uso da voz passiva. Em um outro exercício, tenta-se motivar o porquê de ocorrer a omissão do agente da passiva. Contudo, esses exercícios ficam em segundo plano em relação aos exercícios gramaticais do tipo "encontre o sujeito", "o sujeito pratica ou recebe a ação?", "transforme da voz ativa para a voz passiva".

\subsubsection{PORTUGUÊS: CONEXÃO E USO}

A seção de "Reflexão da Língua" inicia-se a partir de uma proposta de observação crítica das vozes verbais, apresentando alguns exercícios reflexivos sobre a voz ativa e a voz passiva. Sendo assim, nenhuma definição é dada a priori. Nesses exercícios, a intenção 
parece ser a de fazer o aluno compreender, a partir de alguns trechos, como se dá o que chamam de "passividade", que é, sem seguida, definida: "A passividade, em termos gramaticais, é o fato de a ação verbal corresponder a um sujeito gramatical que não exerce papel ativo (atividade) na ação" (DELMANTO; CARVALHO, 2018, p. 129).

Essa primeira definição semântica parece ser problemática, visto que parece implicar que, no papel ativo, teríamos sempre um verbo de atividade. Como vimos, verbos que expressam uma atividade não são os únicos capazes de passivizar, vide os verbos de processo analisados por Bechir (2020), como culminare acarretar, e os verbos de estado psicológico analisados por Cançado (2012), como amar e gostar. Além disso, na seção anterior, discutimos o caso do verbo influenciar, que pode passivizar, mas não é de ação/atividade.

Uma previsão de como a passiva é formada sintaticamente é apresentada: "A voz passiva é construída com os verbos auxiliares ser, estar, ficar, acrescidos de um verbo no particípio passado" (DELMANTO; CARVALHO, 2018, p. 131). Vejamos que esse material não expõe o "esquema" que vimos para os outros livros didáticos, não apresentando a transitividade necessária para que verbos passivizem. Contudo, apesar de este material não explicitar qual transitividade o verbo deve ter para passivizar, ele também não prevê a passiva com VTI, de modo que os exemplos dados ao longo dos exercícios são sempre com VTD.

Esse livro didático é menos categórico tanto em sua definição semântica, quanto em sua definição sintática da passiva, de modo que essas definições ficam em segundo plano. Uma análise textual mais contextualizada é priorizada, propondo, seguindo a BNCC (BRASIL, 2017), que o aluno identifique verbos na voz ativa e na voz passiva antes que sejam dados esquemas categóricos. Por outro lado, os efeitos de sentido da passiva não são trabalhados de forma evidente, sendo negligenciada a motivação por trás dos diferentes usos das vozes verbais.

\subsubsection{GERAÇÃO ALFA}

A matéria de vozes verbais é iniciada por meio de alguns exercícios de reflexão. A partir da leitura de um texto, o exercício inicial instiga o aluno a diferenciar o sujeito das sentenças "Meu ouvido trouxe a mim o som da tua voz" e "O som da sua voz foi trazido para mim pelo meu ouvido" (NOGUEIRA et al., 2018, p. 160), bem como suas diferenças de sentido. A partir disso, são dadas algumas definições (NOGUEIRA et al., 2018, p. 160):

(i) "Os verbos relacionam-se com o sujeito de diferentes maneiras. Os tipos de relação estabelecidas entre eles recebem o nome de vozes verbais".

(ii) "Na voz ativa, a forma verbal indica que o sujeito da oração é o agente da ação". 
(iii) "Na voz passiva, o sujeito da oração é paciente, uma vez que sofre a ação verbal. Essa voz desvia a atenção do sujeito, concentrando-se no resultado da ação".

Nessas definições, temos um viés semântico de entendimento das vozes verbais com uma insistência em definições vagas como as de "praticar"/"sofrer" a ação do verbo. Contudo, chama a atenção explicação em (iii) de que a voz passiva muda o foco para o resultado da ação.

Em seguida, apresenta-se um esquema de construção da voz passiva, que traz a previsão sintática de sua ocorrência. Vejamos abaixo (NOGUEIRA et al., 2018, p. 167):
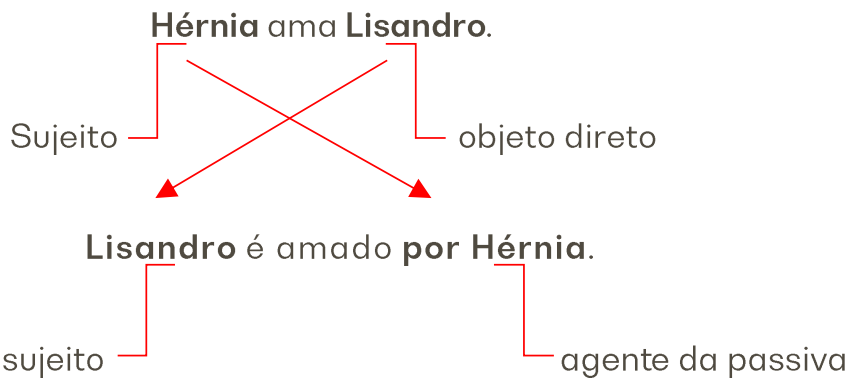

Abaixo do esquema, afirma-se que "para construir uma oração na voz passiva precisamos de um verbo transitivo direto", de forma que "quando a forma verbal está na passiva, o objeto direto passa a ser o sujeito da oração" (NOGUEIRA et al., 2018, p. 161).

É interessante a escolha do verbo amar, um verbo de estado psicológico (CANÇADO, 2012), a título de exemplificação da passiva. Os verbos de estado não são prototipicamente os que mais passivizam. Seguindo estudos como o de Croft (1991), são os verbos de ação os mais prototípicos para essa propriedade. Se observarmos o agrupamento de verbos estativos no VerboWeb, veremos que eles são menos numerosos e possuem menos propriedades sintáticas se comparados aos verbos de ação e de causação, por exemplo.

Alguns exercícios são apresentados no livro com o propósito de que os alunos possam identificar, a partir de um trecho, verbos na voz ativa e na voz passiva, bem como seu efeito de sentido, seguindo o que propõe a BNCC (BRASIL, 2017). Junto a esses exercícios, há outros de interpretação de textos. Em uma seção chamada de "Vozes verbais e efeitos de sentido", é trabalhado como se pode destacar uma informação específica a partir uso da voz passiva, de forma a mostrar que a escolha de uma determinada voz verbal é motivada pelo enunciador.

Em suma, nesse livro, a passiva é definida em termos semânticos, porém é dada como previsível em termos sintáticos. Esse livro é categórico em dizer que a ocorrência da passiva se restringe a VTD. De maneira positiva, o livro apresenta que o uso das 
vozes passiva e ativa têm uma motivação discursiva, tratando também de seus efeitos de sentido.

\subsection{A PASSIVA NO ENSINO MÉDIO}

De acordo com o BNCC (BRASIL, 2018, p. 507), uma das habilidades a serem trabalhadas no Ensino Médio, relacionada a voz passiva, é a habilidade de "analisar, em textos de diferentes gêneros, marcas que expressam a posição do enunciador frente àquilo que é dito" como no uso de "estratégias de impessoalização (uso de terceira pessoa e de voz passiva etc.), com vistas ao incremento da compreensão e da criticidade e ao manejo adequado desses elementos nos textos produzidos, considerando os contextos de produção". Essa habilidade é apontada como pertencendo a competência específica 1, que é apresentada abaixo:

\footnotetext{
Compreender o funcionamento das diferentes linguagens e práticas culturais (artísticas, corporais e verbais) e mobilizar esses conhecimentos na recepção e produção de discursos nos diferentes campos de atuação social e nas diversas mídias, para ampliar as formas de participação social, o entendimento e as possibilidades de explicação e interpretação crítica da realidade e para continuar aprendendo (BRASIL, 2018, p. 507, p. 441).
}

Segundo a BNCC, a competência específica 1 indica que, no Ensino Médio, os alunos devem ser capazes de "desenvolver uma compreensão e análise mais aprofundadas e sistemáticas do funcionamento das diferentes linguagens" (BRASIL, 2018, p. 441).

Nas subseções seguintes, apresentaremos como os 5 livros didáticos do Ensino Médio analisados tratam da voz passiva.

\subsubsection{NOVAS PALAVRAS}

O estudo da "flexão de voz verbal" é introduzido a partir de uma comparação entre duas sentenças com o VTD afundar. "O temporal afundou os velhos barcos" e "Os velhos barcos foram afundados pelo temporal" (AMARAL et al., 2016, p. 204). Assim, aponta-se que o termo "o temporal", na primeira sentença, indica, ao mesmo tempo, o sujeito e o agente, o qual é "aquele que pratica a ação do expressa pelo verbo "afundar" (AMARAL et al., 2016, p. 204). Quanto à segunda sentença, aponta-se que o termo "os velhos barcos" indica ao mesmo tempo o sujeito e o paciente, o qual é definido como "aquele que recebe a ação expressa pelo verbo 'afundar"” (AMARAL et al., 2016, p. 204).

O livro didático, portanto, inicia com uma definição de passiva que combina funções semânticas - agente e paciente - com uma função sintática - a de sujeito. A definição de sujeito também é dada sob um viés sintático nesse livro: "sujeito é o termo (palavra ou expressão) com o qual o verbo estabelece relação de concordância (AMARAL et al., 2016, p. 204). 
O livro define voz verbal como "a flexão que, nos verbos de ação, estabelece uma relação entre o fato verbal e o sujeito, indicando se este pratica ou recebe a ação expressa pelo verbo" (AMARAL et al., 2016, p. 205). A passiva é erroneamente considerada uma construção específica de verbos de ação. Como já discutimos, a passiva pode ocorrer com outros tipos de verbo, como os processuais e os estativos. Interessantemente, nessa definição, ela é considerada uma "flexão", o que nos causa estranhamento, tendo em vista que, o que poderia ser considerado uma flexão seria apenas a marca de particípio que o verbo na passiva possui (-ado(a)). Parece haver uma confusão nessa definição, que mistura os campos da morfologia - a marca do particípio -, sintaxe - a relação entre o sujeito e o verbo, - e semântica - a declaração sobre o tipo semântico verbal.

Na "estrutura verbal" dada para a formação da voz passiva analítica, é apresentado que se deve ter um verbo auxiliar (ser/estar/ficar) + o particípio do verbo principal de ação. Nessa estrutura, não é dada a transitividade do verbo que passiviza. Contudo, exemplos são dados com os VTD afundar (p. 205), divulgar (p. 205), destruir (p. 206) e derrubar (p. 207).

Na seção "toda frase admite voz passiva?", esta questão é discutida por um viés semântico, e não por um viés sintático relacionado à transitividade. Assim, a resposta dada para a questão é a seguinte: "Não. Para que uma frase tenha voz passiva é necessário haver, na voz ativa, um elemento que funcione como paciente/destinatário da ação verbal praticada pelo sujeito" (AMARAL et al., 2016, p. 207). Vejamos, abaixo, os exemplos dados (AMARAL et al., 2016, p. 207):
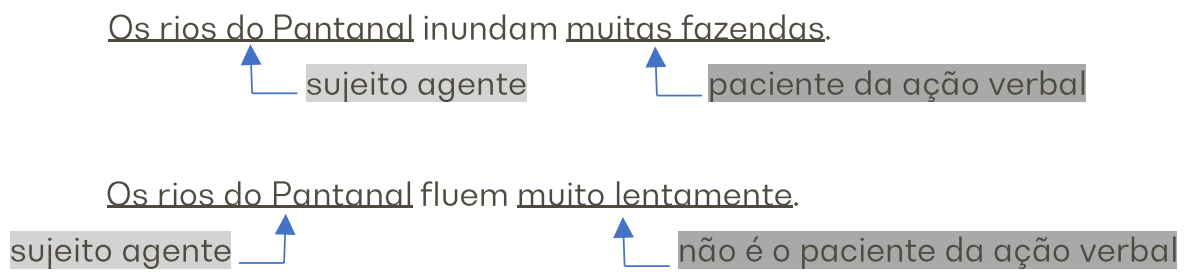

O livro sugere que, como a primeira sentença apresenta um paciente, ela admite a voz passiva; por outro lado, a segunda sentença não possui um paciente e por isso não aceita a passiva. É interessante observar esse tipo de caracterização "ao revés" apresentada por esse livro. Nos livros discutidos até agora, para a formação de passivas vista sob um viés semântico, considera-se que é necessário que o verbo atribua ao sujeito um papel de agente; nesse livro, ao contrário, o foco está na posição de objeto, em que é requerido um papel de paciente.

Bechir (2020) aponta, para os VTI que formam a passiva, a atribuição de papéis temáticos como os de objeto afetado, tema, beneficiário, resultativo e alvo para o objeto. 
Cançado (2012) aponta verbos que atribuem o papel de objeto estativo ao seu objeto e que podem passivizar. Sabemos que, de maneira geral, os livros didáticos valem-se de papéis temáticos de forma mais descritiva. Contudo, mesmo tomando-os descritivamente, a associação de um paciente com a passivização é problemática, haja vista, por exemplo, verbos como pensar.

(25)a. O Ministério do Planejamento pensou na privatização da saúde indígena para evitar concurso público.

b. "Privatização da saúde indígena foi pensada pelo Ministério do Planejamento para evitar concurso público"16.

Tendo em vista o conceito de paciente como aquele que sofre a ação do verbo, os alunos poderiam levantar que, em (25a), "privatização da saúde indígena" não está sofrendo uma ação. Mesmo assim, sua passivização pode ser atestada (25b).

Uma seção interessante do livro questiona "Para que servem, na prática do idioma, as vozes verbais?”. Nessa seção, a passiva é tratada como um mecanismo de realce ao sujeito-paciente. Contudo, não há a promoção de uma discussão aprofundada levando em conta as facetas semântica, pragmática e discursiva da passiva com ancoragem em textos de circulação social real.

Em suma, prevalece, nesse livro, um viés semântico sobre a passiva. Apesar de ele não apresentar nenhum VTI que possa ser capaz de fazer a passivização, o livro não afirma categoricamente que a passiva ocorre apenas com VTD. Os efeitos de sentido da passiva, alinhados a uma análise da posição do enunciador frente àquilo que é dito, que deveriam ser tratados de acordo com a BNCC (BRASIL, 2018), são tratados apenas superficialmente.

\subsubsection{ESFERAS DA LINGUAGEM}

Na seção "Vozes verbais: o sujeito e o agente", temos uma primeira definição, a de voz: "o modo como o sujeito gramatical se relaciona com o verbo na oração caracteriza o que a gramática normativa chama de voz" (CAMPOS; ASSUMPÇÃO, 2016, p. 330). Essa primeira definição causa estranhamento, visto que a voz diz muito mais sobre a relação entre papéis semânticos e posições sintáticas do que sobre relação entre o verbo e o sujeito.

A partir dessa definição, há algumas questões com base em trechos de um texto. Nessas questões, pergunta-se se os sujeitos de morrere de proibir são agentes das ações 
verbais, bem como sobre a diferença de efeito de sentido entre uma sentença na voz ativa e outra na passiva.

Outras definições são dadas: "A gramática normativa estabelece que, quando o sujeito é agente, o verbo está na voz ativa; quando é paciente, o verbo está na voz passiva” (CAMPOS; ASSUMPÇÃO, 2016, p. 331). Essa afirmação é facilmente falseável, haja vista, por exemplo, o verbo "apanhar" na sentença "O irmão mais novo apanhou do mais velho" e o verbo "receber" na sentença "A mulher recebeu a carta". Os sujeitos desses verbos recebem o papel semântico de paciente, no entanto, as sentenças não estão na voz passiva. Como podemos observar, nesse livro, a primeira caracterização da voz passiva em si é semântica. Contudo, o uso da semântica sem rigor teórico mostra-se problemático.

Há alguns exercícios sobre a voz passiva, separados em seções denominadas "o ponto de vista gramatical" e "o ponto de vista discursivo". Nessa segunda seção, a voz passiva não é trabalhada, mas somente a voz reflexiva. Na seção seguinte, chamada de "usando os mecanismos linguísticos discursivos", temos um exemplo de texto como pretexto: um fragmento de A cartomante, de Machado de Assis, é apresentado, e a única questão que se faz é sintática: "No texto, qual é o sujeito de ser amada?". Como observa Lajolo (1985), o texto costuma virar pretexto em situações escolares, apresentando-se como ser intermediário de aprendizagens outras que não ele mesmo. Nesse sentido, o livro perde a oportunidade de permitir que o texto cumpra, também, sua função literária. Soares (2011) faz uma importante crítica ao processo de escolarização da literatura e do estudo do texto, que apresenta-se como inadequado na medida em que se limita à má fragmentação dos textos e ao seu uso para fins puramente gramaticais.

Em resumo, o livro "Esferas das Linguagens" trata da passiva a partir de um viés prevalentemente semântico. Contudo, vale-se de semântica arbitrária, não criteriosa. Ademais, o livro não vai além, não trabalhando os aspectos pragmáticos e discursivos da voz passiva e tratando de seus efeitos de sentido de forma superficial. É interessante observar que esse livro não apresenta um "esquema" sintático para a passiva, nem dita que ela ocorre apenas com VTD. No entanto, nenhum insight sobre a passiva com VTI é apresentado, assim como era esperado.

\subsubsection{VIVA PORTUGUÊS}

A seção de "conhecimentos linguísticos" inicia-se com definições sobre o que é voz verbal, explicitando as vozes ativa e passiva. As definições apresentadas são semânticas, indicando que o agente "pratica" a ação do verbo e que o paciente "sofre" essa ação. Depois, alguns exercícios são dados. 
Há uma questão que apresenta uma sentença com o VTD ganhar. "[...] três grandes vencedores [...] ganharão um curso em Harvard” (CAMPOS et al., 2016, p. 214). Em (c), pergunta-se: "qual é a função sintática de "um curso em Harvard'?" (CAMPOS et al., 2016, p. 14). Podemos supor que esse exercício quer levar o aluno a compreender que há um OD nesta sentença na voz ativa. A partir disso, uma visão sintática da passiva passa a prevalecer.

No próximo exercício, há, em uma coluna, duas sentenças na voz ativa e, em outra, duas sentenças na voz passiva. A partir disso, temos a seguinte questão: "a) Identifique o sujeito e o objeto direto dos verbos transitivos diretos das frases que estão na coluna da voz passiva" (CAMPOS et al., 2016, p. 214, grifo nosso). Podemos inferir que esta questão tem o intuito de fazer com que o aluno reconheça que a voz passiva é construída com VTD. Essa inferência é confirmada quando, na questão seguinte, há algumas orientações sobre como passar da voz ativa para a passiva. As duas primeiras orientações dadas já explicitam que, para a transformação para a voz passiva, deve haver um OD. Vejamos o esquema apresentado (CAMPOS et al., 2016, p. 215, grifo nosso):

1) Comece pelo sujeito paciente: identifique o objeto direto e ponha-o na posição de sujeito. 2) Deixe um bom espaço na linha e coloque o antigo sujeito no lugar do objeto direto (ele se transformará em agente da passiva)

Além de exercícios que pedem que os alunos passem da voz ativa para a passiva, questões sobre o efeito de sentido da passiva são apresentadas. Vejamos algumas delas (CAMPOS et al., 2016, p. 217):

4) Em sua opinião (...) as frases na voz ativa apresentam alguma diferença de interpretação em relação àquelas que foram transformadas em passiva?

6) c) Muitas vezes, no uso do dia-a-dia, o agente da passiva não aparece em uma frase (...). É possível saber, pelo contexto, quem praticará a ação de premiar?

Na conclusão da seção, há um quadro explicando que a escolha da voz verbal revela diferentes pontos de vista. Vejamos um trecho (CAMPOS et al., 2016, p. 217):

\footnotetext{
O uso da voz passiva analítica ou da passiva sintética, sem agente expresso, está relacionado à possibilidade de se querer/poder ou não revelar o agente, ou seja, o responsável pela ação expressa pelo verbo, ou mesmo à possibilidade de se abreviar a informação. Para isso, é muito importante que o autor da frase saiba que perspectiva pretende utilizar [...].
}

Nesse livro, há uma grande ênfase na estrutura sintática na passiva e na informação de que ela ocorre apenas com VTD. Portanto, a passiva é dada como sendo prevista sintaticamente. Contudo, os efeitos de sentido da passiva também são demonstrados. Sendo assim, o livro parece se preocupar em seguir a BNCC no que se refere à habilidade de analisar "a posição do enunciador frente àquilo que é dito" (BRASIL, 2018, p. 507) nas vozes verbais. O que falta a esse respeito, entretanto, é uma visão mais discursiva da 
passiva, focando em seu uso no texto ao invés de seu uso em sentenças isoladas. Como notamos, nenhum texto que demonstre uma prática discursiva real é apresentado, o que impede o aluno de fazer uma "interpretação crítica da realidade", como sugere a competência específica 1 da BNCC (BRASIL, 2018).

\subsubsection{PORTUGUÊS: CONTEXTO, INTERLOCUÇÃO E SENTIDO}

Na seção denominada "as noções de voz e aspecto verbal", é apresentada uma definição de vozes verbais. A definição apresentada é sintática, similar à definição dada no livro "Esferas das Linguagens": "A voz verbal indica a relação que se estabelece entre o verbo e o seu sujeito sintático" (ABAURRE et al., 2016, p. 227). Na seção 3.2.2, levantamos a problemática desse tipo de definição. Por sua vez, para a definição da voz ativa, temos:

\footnotetext{
Diz-se que o verbo está na voz passiva quando o sujeito é o paciente do processo expresso pelo verbo, ou seja, esse sujeito sintático sofre a ação verbal. Apenas os verbos transitivos diretos, que sintaticamente têm como complementos objetos diretos, podem expressar voz passiva" (ABAURRE et al., 2016, p. 227, grifo nosso).
}

Nessa definição, semanticamente, vemos a caracterização do sujeito como aquele que "sofre a ação verbal". Além disso, sintaticamente, é apresentada uma regra categórica de que apenas os VTD podem expressar a voz passiva.

Para a exposição da passiva analítica, o livro apresenta a seguinte tirinha (ABAURRE et al., 2016, p. 227):

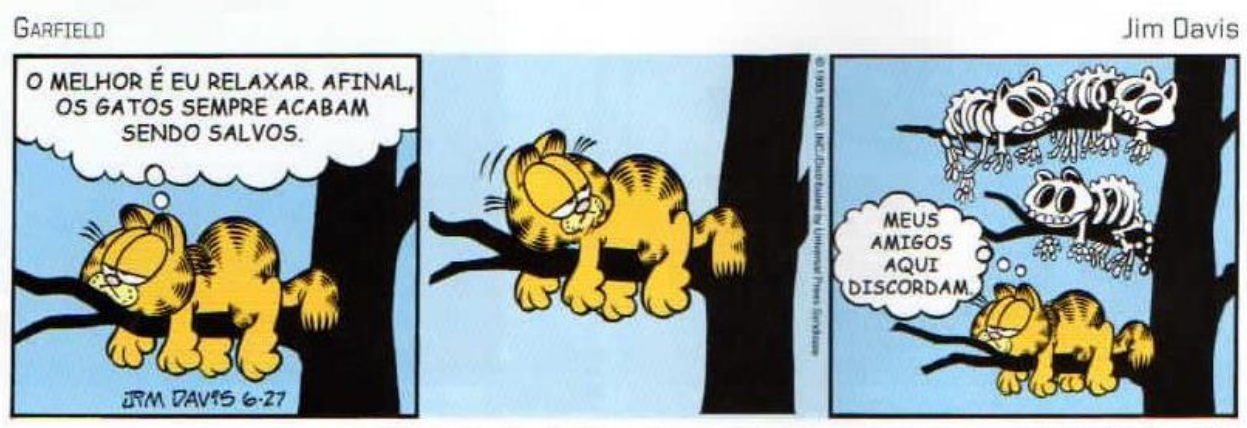

A DAVIS, Jim. Garfield: taneladas de diversão. Porto Alegre: LEPM, 2006. p. 102.

A partir da tirinha acima, o livro correlaciona a sentença apresentada na voz passiva - "os gatos sempre acabam sendo salvos" - com a sentença ativa correspondente "alguém sempre acaba salvando os gatos", explicando que "a opção pela voz passiva faz com que o sujeito sintático [os gatos] ganhe destaque na construção e "[...] torna-se desnecessária a explicitação do agente da ação verbal, pois o que Garfield quis dizer é que os gatos, por serem especiais, sempre são salvos” (ABAURRE et al., 2016, p. 227). Apesar de haver uma referência à função discursiva da voz passiva nessa explicação, esta é pouco explorada. De forma mais abrangente, poderia ter sido explorado o efeito 
do humor da tira, que é construído pelo uso da voz passiva. Se a voz ativa fosse utilizada, exprimindo o agente da ação, como em "Os bombeiros sempre acabam salvando os gatos", por exemplo, teríamos uma ênfase na ação dos bombeiros, sendo eles responsabilizados pelo salvamento dos gatos. Por outro lado, a voz passiva deixa oculto o agente da ação, que não pode ser responsabilizado, e foca no resultado de os gatos serem salvos; no entanto, há uma quebra da expectativa no último quadrinho, já que esse resultado é negado.

No único exercício apresentado no livro especificamente sobre a voz passiva analítica, há outra tirinha. Sobre essa tirinha, além de haver uma questão sobre a identificação do agente de uma sentença da tira, há uma questão que pede que o aluno explique o efeito de sentido criado pelo uso da voz passiva.

O livro apresenta uma curta passagem sobre a voz passiva e, apesar de não apresentar nenhum "esquema" da passagem da voz ativa para a passiva, é categórico quanto à fórmula sintática da passiva, com VTD. Quanto ao viés semântico, as definições apresentadas são arbitrárias. Apesar do fato de o efeito de sentido da passiva ser mencionado, uma interpretação mais crítica de seu uso, como sugere a BNCC (BRASIL, 2018), não é possibilitada.

\subsubsection{SER PROTAGONISTA}

A partir de um anúncio publicitário, as vozes verbais são tratadas brevemente, em apenas uma página. A tentativa é de que elas sejam tomadas sob um viés mais discursivo, com foco nos seus efeitos de sentidos. Além disso, tenta-se mostrar qual função semântica ganha mais destaque: no caso da voz ativa, o agente; no caso da voz passiva, o paciente. Sendo assim, detalhes de como a voz passiva é estruturada sintaticamente não são apresentados. Semanticamente, o livro não inova muito, e segue a descrição do papel de agente como aquele que "pratica a ação" e do papel de paciente como aquele que "sofre a ação".

Sobre a motivação para o uso da passiva, o livro apresenta o seguinte: "a voz passiva está associada a importantes efeitos de sentido, como o apagamento ou a atenuação do agente da ação verbal no enunciado" (BARRETO et al, 2016, p. 225). Essa ideia, no entanto, não é levada a uma discussão mais profunda, mantendo-se superficial. De maneira geral, o livro não apresenta a estrutura sintática da passiva, mas também não apresenta um insight sobre a possibilidade de ela ocorrer com verbos de transitividade indireta. Os únicos exemplos apresentados no livro são de VTD, como o verbo fazer't?

17 Tivemos acesso à versão anterior do livro 'Ser protagonista' (RAMOS, 2013) e observamos que, nela, o exemplo dado era com o verbo influenciar, que já demonstramos, na seção 3.1.3, ser problemático para a caracterização 
Há uma tentativa de seguir a BNCC (BRASIL, 2018) trazendo o foco para a passivização como uma estratégia motivada, contudo, isso não se consolida. Mesmo na tentativa de ressaltar os aspectos discursivos da passivização, aspectos gramaticais parecem continuar figurando em primeiro plano e a propriedade de passivização é pouco aproveitada.

\subsection{COMO OS LIVROS DIDÁTICOS PODERIAM TRATAR A PASSIVA?}

Observamos que, nos livros didáticos tanto do Ensino Fundamental quanto do Ensino Médio, a passiva é tratada, de maneira geral, como um mecanismo sintático-semântico de alternância entre elementos da sentença. Regras sintáticas para essa alternação de elementos são comumente apresentadas: é necessário haver um VTD na estrutura sentencial para a passivização ocorrer. Regras semânticas também são dadas na maioria dos casos: o papel de agente (aquele que "pratica" a ação do verbo) e de paciente (aquele que "recebe" a ação do verbo) são obrigatórios. Por outro lado, uma visão discursiva da passiva é negligenciada. Mesmo quando se apresenta a motivação para seu uso e seus efeitos de sentido, isso é feito em segundo plano ou de forma descontextualizada das práticas sociais reais.

Quando a passivização é apresentada a partir de seu uso em textos, esses, na maioria das vezes, apresentam-se como um pretexto para a aplicação de regras sintáticas e semânticas, que devem ser memorizadas pelos alunos. Pode-se notar que os livros didáticos analisados valem-se da leitura primordialmente para a observação dos aspectos puramente gramaticais da passiva. Nesse sentido, uma vez que a leitura é utilizada sempre em prol da análise linguística, perde-se a oportunidade de tomá-la como uma forma de participação e de interação social.

Além disso, na matéria de passiva, a maioria dos exercícios apresentados nos livros didáticos analisados não propõe um trabalho com uma diversidade de gêneros textuais. Também não é trabalhada de maneira ampla a real interpretação das relações de sentido dos textos escritos em voz ativa e em voz passiva. Uma simples cópia de informações, típica de uma abordagem puramente tradicional, é privilegiada em detrimento da interpretação textual.

A partir dos anos 80 , seguindo os avanços em pesquisas linguísticas, houve uma colaboração na revisão dos objetivos do ensino de português. A partir disso, foram adotados novos paradigmas de análise da linguagem, considerando sua aplicação em contextos sociais junto a suas diversas formas de manifestação (HUBES; CHOPTIAN, 2014).

da passiva como ocorrendo apenas com verbos de ação agentivos. A troca dos exemplos já demonstra, em si, a problemática da previsão semântica de ocorrência da passiva. 
Assim, passou a ser abandonado o dogmatismo do ensino da gramática tradicional fragmentada e descontextualizada.

Seguindo essa linha, levantamos a importância de os estudos linguísticos servirem de fonte para o ensino de português. Nesse trabalho, propomos que a passivização seja vista de maneira mais ampla, não sendo restringida pela transitividade do verbo. Sendo assim, a passiva não deve ser vista como uma simples forma de se "estruturar" a sentença, mas como um poderoso mecanismo semântico-discursivo da língua. Sendo um recurso desse tipo, a passiva parece ter poucas restrições sintáticas, podendo ocorrer com verbos de diferentes transitividades; ademais, ela tem poucas restrições semânticas, ocorrendo com diferentes tipos de verbos.

O que podemos observar é que a passiva, prototipicamente, parece preferir os verbos de ação, que possuem, como estrutura mais frequente no PB, com base nos estudos de como os de Hopper e Thompsom (1980) e Croft (1991), a estrutura transitiva direta 'S + V + OD'. Contudo, as restrições semântico-lexicais para a formação de passivas parecem ser muito específicas, sendo difícil se fazer uma regra dos papéis semânticos que os verbos devem atribuir ao sujeito e ao objeto para que a passivização ocorra. Ademais, nos questionamos: até que ponto a formulação dessas regras é justificável para o ensino?

Mais relevante para o ensino é demonstrar as motivações para o uso ou não da voz passiva em textos de determinados gêneros textuais, de maneira a promover o desenvolvimento de uma visão crítica do aluno frente a esse tipo de formação. É relevante trabalhar a diferença de ênfase que se dá em determinada sentença na voz ativa, se comparada à mesma sentença na voz passiva: na primeira, temos o foco na ação feita por um participante; na segunda, o foco está no resultado. Desse modo, espera-se que o aluno possa, ele mesmo, na posição de escritor, produzir sentenças na voz passiva consciente e criticamente.

Como assevera Franchi (2006, p. 41), "o ideal não é o aluno passivo e recipiente, mas ativo e interferente: o conhecimento tem que resultar de um processo de construção conduzido pelo próprio sujeito". Franchi propõe, não o abandono da gramática, mas seu tratamento de forma mais elaborada, tendo em vista que a gramática só é aprendida "quando relacionada a uma vivência rica da língua materna, quando construída pelo aluno como resultado de seu próprio modo de operar com as expressões e sobre as expressões, quando os fatos da língua são fatos de um trabalho efetivo e não exemplos descolados da vida" (Franchi, 2006: p. 75).

Parece-nos mais atrativo que a passiva seja tratada, nos livros didáticos, a partir de seu uso em diferentes gêneros textuais. Marcuschi (2002) defende que os gêneros textuais são fenômenos sócio-históricos, entidades sócio discursivas e formas de ação social, mostrando que eles são instrumentos maleáveis, e não estanques, a serviço da vida cultural e social. Concordamos com o autor que "o trabalho com os gêneros textuais 
é uma extraordinária oportunidade de se lidar com a língua em seus mais diversos usos autênticos no dia-a-dia" (MARCUSCHI, 2002, p. 35). A matéria da passiva é um excelente canal para esse trabalho.

\section{CONSIDERAÇÕES FINAIS}

Esse trabalho, com o objetivo de verificar como voz passiva é abordada em livros didáticos brasileiros, desenvolveu uma análise de 5 livros do Ensino Fundamental II e 5 livros do Ensino Médio, aprovados, respectivamente, pelo PNLD de 2020 e pelo PNLD de 2018. Levantamos a hipótese de que os livros didáticos apresentam como fórmula para a passiva que esta seja formada apenas com VTD, sendo prevista sintaticamente.

Nesses livros, encontramos uma tendência de limitar a passiva em relação a transitividade verbal, apresentando, na maioria das vezes, "regras" demonstrando que a passiva ocorre apenas com verbos de transitividade direta. Sendo assim, esses livros não apresentam nenhum tipo de insight sobre a ocorrência da passiva com VTI. Além disso, uma limitação semântica foi amplamente encontrada nos materiais analisados, a de que a passiva só pode ser elaborada a partir de verbos de ação com sujeitos agentivos. Percebemos também que, nos livros de nossa amostra, a passiva continua sendo tratada com ênfase em seus aspectos gramaticais em detrimento de sua motivação de uso.

A passiva é um recurso semântico-discursivo da língua, não tendo restrições normativas rigorosas no âmbito semântico ou sintático. Tendo isso em vista, nossa proposta é de que a passivização seja vista de maneira mais ampla, não devendo ser tratada, nos materiais didáticos, a partir de suas restrições gramaticais, mas a partir de suas motivações discursivas e de seus efeitos de sentido.

\section{REFERÊNCIAS}

ABAURRE, M. B. et al. Português: contexto, interlocução e sentido. - 3. ed. - São Paulo: Moderna, 2016

AMARAL, E. et al. Novas Palavras: $2^{\circ}$ ano. - 3. ed. - São Paulo: FTD, 2016.

AMARAL, L.; CANÇADO, M. Argument structure of activity verbs in Brazilian Portuguese. Semantics-Syntax Interface, v. 2, n. 2, 2015 .

BECHARA, E. Moderna gramática portuguesa. Rio de Janeiro: Nova Fronteira, 2009

BECHIR, T. Uma análise sintático-semântica dos verbos transitivos indiretos do português brasileiro. Dissertação de Mestrado, FALE, UFMG, Belo Horizonte, 2020.

BARRETO, R. G. et al. Ser Protagonista: língua portuguesa: $2^{\circ}$ ano. - 3. ed. - São Paulo: Edições SM, 2016. 
BRASIL. Ministério da Educação. PNLD 2020: língua portuguesa - guia de livros didáticos - Ensino Médio/Ministério da Educação - Secretária de Educação Básica - SEB - Fundo Nacional de Desenvolvimento da Educação. Brasília, DF: Ministério da Educação, Secretaria de Educação Básica, 2019

BRASIL. Ministério da Educação. PNLD 2018: língua portuguesa - guia de livros didáticos - Ensino Médio/Ministério da Educação - Secretária de Educação Básica - SEB - Fundo Nacional de Desenvolvimento da Educação. Brasília, DF: Ministério da Educação, Secretaria de Educação Básica, 2017.

BRASIL. Base Nacional Comum Curricular. Ensino Médio. Brasília: MEC/Secretaria de Educação Básica, 2018.

BRASIL. Base Nacional Comum Curricular. Educação Infantil e Ensino Fundamental. Brasília: MEC/Secretaria de Educação Básica, 2017.

CAMACHO, R. G. Construções passiva e impessoal: distinções funcionais. ALFA: Revista de Linguística, São Paulo, v. 44, 2001. Disponível em: <https://periodicos.fclar.unesp.br/alfa/article/view/4206>. Acesso em: 20 jun. 2021.

CAMPOS, M. I.; ASSUMPÇÃO, N. Esferas das Linguagens: $3^{\circ}$ ano. São Paulo: FTD, 2016.

CAMPOS, E. et al. Viva português: Ensino Médio. - 1. ed. - São Paulo: Ática, 2016.

CANÇADO, M; AMARAL, L.; MEIRELLES, L. VerboWeb: classificação sintático-semântica dos verbos do português brasileiro. Banco de dados lexicais. UFMG, 2017. Disponível em: <http://www.letras.ufmg.br/verboweb/> Acesso em: 18/06/2021.

CANÇADO, M.; AMARAL, L. Introdução à Semântica Lexical: papéis temáticos, aspecto lexical e decomposição de predicados. Petrópolis: Editora Vozes, 2016

CANÇADO, M. Verbos psicológicos: uma classe relevante gramaticalmente? Revista Veredas, v. 16, n. 2, 2012.

CANÇADO, M. Uma aplicação da teoria generalizada dos papéis temáticos: verbos psicológicos. Revista do GEL, 2002 .

CANÇADO, M. O Lugar da Semântica em uma Teoria Gramatical. Estudos Linguísticos 29: 67- 78, 2000.

CANÇADO, M. Verbos Psicológicos: A Relevância dos Papéis Temáticos vistos sob a Ótica de uma Semântica Representacional. Tese de Doutorado, IEL, Unicamp, Campinas, 1995.

CEGALLA, D. P. Novíssima Gramática da Língua Portuguesa. 48. ed., São Paulo: Companhia Editora Nacional, 2008.

CIRÍACO, L. A Hipótese do contínuo entre o léxico e a gramática e as construções incoativas, mediais e passivas do PB. Tese de Doutorado, FALE, UFMG, Belo Horizonte, 2011

CROFT, W. Syntactic Categories and Grammatical Relations. Chicago: University of Chicago Press, 1991.

CUNHA, C.; CINTRA, L. Nova Gramática do Português Contemporâneo. Rio de Janeiro: Nova Fronteira. 2001.

DELMANTO, D.; CARVALHO, L. Português: conexão e uso. 8ªno. São Paulo: Saraiva, 2018.

FRANCHI, C. Criatividade e Gramática. In: FRANCHI, C. [com] NEGRÃO, E. V.; MÜLLER, A.

L. Mas o que é mesmo gramática? São Paulo: Parábola, 2006.

GODOY, L. Ensino de gramática em PLA: um projeto e seus resultados. Revista de Ciências Humanas, v. 1, n. 18 2018.

GODOY, L. Preposições e os verbos transitivos indiretos: interface sintaxe-semântica lexical. Revista da ABRALIN, v.7, n.1, 2008.

HOPPER, P. J.; THOMPSON, S. A. Transitivity in Grammar and Discourse. Language, v. 56, n. 2, p. 251-299, 1980.

HUBES, T.; CHOPTIAN, L. Concepções de Leitura: análise de atividades de um livro didático de língua portuguesa. Revista Educação e Linguagens, v. 3, n. 5, 2014. 
KURY, A. G. Novas Lições de Análise Sintática. São Paulo: Ática. 2000.

LAJOLO, M. O texto não é pretexto. In: ZILBERMAN, R. (org.) Leitura em crise na escola. 5a. ed. Porto Alegre: Mercado Aberto, p. 51-62, 1985.

LEVIN, B; RAPPAPORT HOVAV, M. Argument Realization. Cambridge: Cambridge University Press, 2005.

LEVIN, B. English Verb Classes and Alternations: A Preliminary Investigation. Chicago: University of Chicago Press, 1993

MEIRELLES, L. L. A fatoração de argumentos verbais no PB. Tese de Doutorado. FALE, UFMG, Belo Horizonte, 2018.

MENDONÇA, S. A abordagem da voz passiva em livros didáticos de português para estrangeiros e inglês para brasileiros: uma análise preliminar sob a perspectiva da Linguística Funcional. Monografia (Especialização). UFRGS, 2015.

NASCIMENTO, T. Os verbos beneficiários de contato no português brasileiro. Monografia de Bacharelado. FALE, UFMG, Belo Horizonte, 2015.

NEVES, M. H. M. Gramática na escola. $8^{a}$ ed. São Paulo: Contexto, 2007.

NOGUEIRA, E. et al. Geração Alfa: língua portuguesa: $8^{\circ}$ ano. - 2. ed. - São Paulo: Edições SM, 2018.

OLIVEIRA, T. A.; ARAÚJJ, L. A. Tecendo Linguagens: Língua Portuguesa: $8^{\circ}$ ano. - 5. ed. - São Paulo: IBEP, 2018.

ORMINDO, W.; SINISCALCHI, C. Se liga na língua: leitura, produção de texto e linguagem. - 1. ed. - São Paulo: Moderna, 2018.

RAMOS, R. A (ed.). Ser Protagonista: língua portuguesa: $2^{\circ}$ ano. - 3. ed. - São Paulo: Edições SM, 2013.

ROCHA LIMA, C. H. da. Gramática normativa da língua portuguesa. 43. ed. Rio de Janeiro: José Olympio, 2012.

SALLORENZO, L. 2018. Gramática da manipulação. Belo Horizonte: Quintal Edições, 2018.

SANTOS, J. R. P. Alternância passiva com verbos transitivos indiretos no português do Brasil. Dissertação de Mestrado, Instituto de Letras, Universidade de Brasília, Brasília, 2013.

SOARES, M. A escolarização da literatura infantil e juvenil. In: EVANGELISTA, A. A. M.; B; MACHADO, M. Z. (orgs.) Escolarização da leitura literária, p. 17-48, 2011

TEIXEIRA et al. Apoema: português: $8^{\circ}$ ano. São Paulo: Editora do Brasil, 2018.

VENDLER, Z. Linguistics in Philosophy. Ithaca: Cornell, 1967.

VIEIRA, S. R. \& BRANDÃO, S. F. Ensino de Gramática: descrição e uso. São Paulo: Contexto, 2009. 